\title{
Trans-2-Aminocyclohexanols as pH-triggered molecular switches
}

\author{
Vyacheslav V. Samoshin,* a,b Barbora Brazdova, ${ }^{\text {b }}$ Vyacheslav A. Chertkov, ${ }^{\text {c }}$ \\ Dmitriy E. Gremyachinskiy, ${ }^{\text {a,b }}$ Alla K. Shestakova, ${ }^{d}$ Elena K. Dobretsova, ${ }^{a}$ Lidia P. Vatlina, \\ Jing Yuan, ${ }^{b}$ and Hans-Jörg Schneider ${ }^{f}$ \\ ${ }^{a}$ Lomonosov Moscow State Academy of Fine Chemical Technology, Vernadsky Prospect 86, \\ Moscow, 117571, Russia \\ ${ }^{b}$ Department of Chemistry, University of the Pacific, Stockton, CA 95211, USA \\ ${ }^{c}$ Department of Chemistry, Lomonosov Moscow State University, Moscow, 119899, Russia \\ ${ }^{d}$ State Research Institute of Chemistry and Technology of Organoelement Compounds, 111123, \\ Moscow, Russia \\ ${ }^{e}$ Ushinsky Yaroslavl State Pedagogic University, Yaroslavl, 150000, Russia \\ ${ }^{f}$ Fachrichtung Organische Chemie der Universität des Saarlandes, D 66041 Saarbrücken, \\ Germany \\ E-mail:vssamoshin@pacific.edu; h-j.schneider@mx.uni-saarland.de
}

Dedicated to Academician Nikolai S. Zefirov on his $70^{\text {th }}$ birthday

(received 24 Dec 04; accepted 21 Apr 05; published on the web 06 May 05)

\begin{abstract}
Cyclohexane-based conformationally controlled ionophores, the emerging new class of molecular switches, provide a new and promising approach to allosteric systems with negative cooperativity. Protonation of trans-2-aminocyclohexanols leads to dramatic conformational changes: due to an intramolecular hydrogen bond, a conformer with equatorial position of ammonio- and hydroxy-groups becomes predominant. Thus, these structures can serve as powerful conformational $\mathrm{pH}$-triggers. The trans-2-aminocyclohexanol moiety has been used for $\mathrm{pH}$-triggered conformational switching of a crown ether and a podand, and their complexes with potassium ion.
\end{abstract}

Keywords: Molecular pH-switches, trans-2-aminocyclohexanols, cyclohexano crown-ether, conformational transmitters

\section{Introduction}

The development of molecular switches is of great current interest in view of their possible use in many applications, such as drug release, new sensor techniques or information storage and 
transmission. Molecular switches are molecules that can reversibly change their conformations and related properties under external influence. ${ }^{1-3}$ Allosteric switches are host compounds containing at least two spatially separated binding sites that are conformationally coupled. When one site is occupied, it changes conformation, and this 'signal', mechanically transmitted by the structure of the molecule, induces a conformational change in the second site, thus increasing (positive cooperativity) or decreasing (negative cooperativity) its affinity to an appropriate guest. Negative cooperativity has been less explored than the positive, though it may be more interesting for applications, such as membrane transport, drug delivery, catalysis, etc. ${ }^{1-3}$ For example, the presence of a particular effector compound, or a particular $\mathrm{pH}$ value could lead to the release or to the uptake of a biologically active substance.

Cyclohexane-based conformationally controlled ionophores provide a new and promising approach to allosteric systems with negative cooperativity. Conformational control via introduction of various substituent(s) into a trans-fused six-membered cycle was proposed by us as a new principle for modification of the complexing ability of (cyclohexano)crown compounds and non-macrocyclic ionophores (podands). ${ }^{4-23}$ Similar ideas were suggested for cyclohexanebased podands by Raban et al. ${ }^{24-27}$ In these structures, a substituent plays a role of 'conformational lever', or 'counterbalance', and the cyclohexane moiety serves as a mechanical transmitter. The cyclohexane machinery can also mimic an allosteric effect by transmitting a conformational change (signal) from one complexing center (e.g. a macroheterocycle or podand) to another site, which results in an externally controlled conformational equilibrium of the type $\mathbf{1 A} \rightleftarrows \mathbf{1 B}$ (Scheme 1). ${ }^{16,19-21,23} \mathrm{~A}$ change by external influence of non-bonded interactions between groups $\mathrm{W}$ and $\mathrm{Z}$ (and/or $\mathrm{X}$ and $\mathrm{Y}$ ) in structures $\mathbf{1}$ will change the relative stability of conformers. By affecting these interactions one can control the position of conformational equilibrium of the type $\mathbf{1 A} \rightleftarrows \mathbf{1 B}$, thus controlling the shape and the complexing ability of the macrocycle or podand. These ideas were successfully explored also by Costero et al., ${ }^{28-32}$ and were expanded by Koert et al. ${ }^{33-38}$ to $c i s$-decaline and perhydroanthracene derivatives.

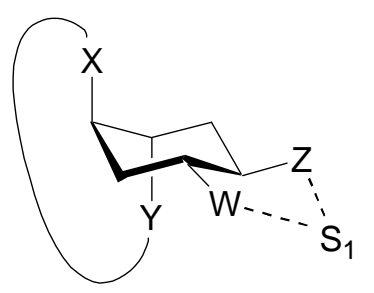

$1 \mathrm{~A}$

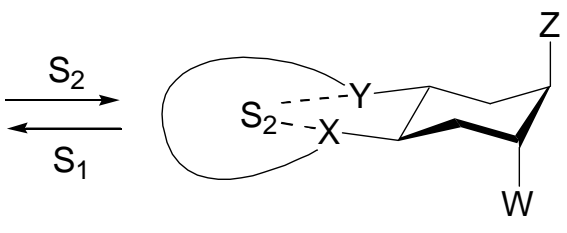

1B

\section{Scheme 1}

A promising type of a conformational trigger is provided by trans-2-aminocyclohexanol moiety. trans-1,2-Cyclohexanediols and trans-2-aminocyclohexanols are well known to strongly prefer the diequatorial conformation, in part due to an intramolecular hydrogen bonding between 
vicinal substituents. ${ }^{20,23,39-42}$ Therefore, these structural moieties can be used as conformational counterbalances or locks.

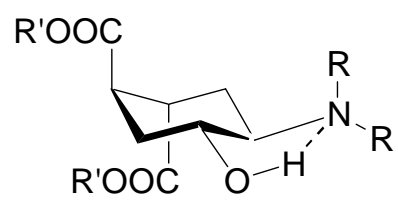

2A

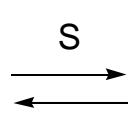

2B

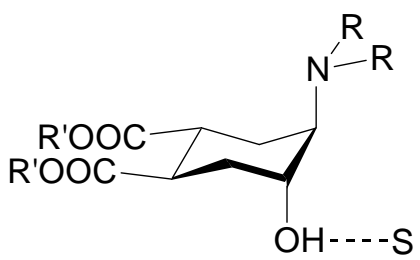

\section{Scheme 2}

We found ${ }^{20}$ that the trans-2-morpholylcyclohexanol derivative $\left(2, \mathrm{NR}_{2}=\right.$ morpholyl $\mathrm{R}^{\prime}=\mathrm{Et}$; Scheme 2) adopted predominantly conformation $\mathbf{2 A}$ in $\mathrm{CDCl}_{3}$, but conformation $\mathbf{2 B}$ in methanol or DMSO. This dramatic change, which exceeded $10 \mathrm{~kJ} / \mathrm{mol}$ in terms of the relative conformational stability, was attributed to destruction of the stabilizing intramolecular $\mathrm{OH} \cdots \mathrm{N}$ hydrogen bond in $\mathbf{2 A}$ by the hydrogen bond acceptor solvents. ${ }^{20}$ Similar results were obtained earlier for trans-2-o-tolyl-cis-4-hydroxy(amino)-trans-5-amino(hydroxy)cyclohexanols ${ }^{39}$ and some 5-alkyl-trans-2-aminocyclohexanols. ${ }^{40}$ Thus, the trans-2-aminocyclohexanol moiety provides a promising type of a rapid conformational trigger.

As we suggested in a preliminary publication, ${ }^{23}$ another way to control such a conformational equilibrium is an addition of acid to protonate the amino group, and to generate a stronger intramolecular hydrogen bond of $\mathrm{O} \cdots \mathrm{H}_{-} \mathrm{N}^{+}$type, ${ }^{23,39}$ e.g. in 3A (Scheme 3). ${ }^{23}$ This bond would stabilize conformation $\mathbf{3 A}$, thus moving the ester groups away from each other, and decreasing their potential ability to interact with another molecule or ion, for example to form complexes like 1B.

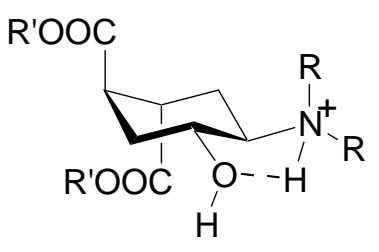

3A

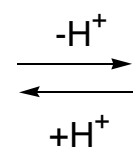

$+\mathrm{H}^{+}$

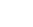

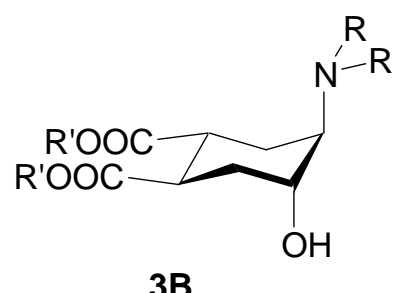

3B

\section{Scheme 3}

\section{Results and Discussion}

To further explore the use of trans-2-aminocyclohexanol moiety as a conformational trigger, we synthesized the model compounds 5-11 (Scheme 4), and evaluated their conformational behaviour in various conditions (Table 1). 
<smiles>O=C(O[Na])[C]1CC=CC[C@H]1C(=O)O[Na]</smiles>

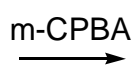<smiles>CCOC(=O)[C@H]1CC2OC2C[C@H]1C(=O)OCC</smiles>

4

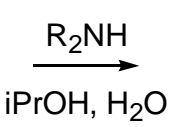

iPrOH, $\mathrm{H}_{2} \mathrm{O}$<smiles>[R]N([R])[C@H]1C[C@H](C(=O)OCC)[C@H](C(=O)OCC)C[C@H]1O</smiles>

5-9

$\left.5(\mathrm{R}=\mathrm{Me}), \mathbf{6}(\mathrm{R}=\mathrm{Et}), \mathbf{7}\left(\mathrm{R}, \mathrm{R}=-\left(\mathrm{CH}_{2}\right)_{4}^{-}\right), \mathbf{8}\left(\mathrm{R}, \mathrm{R}=-\left(\mathrm{CH}_{2}\right)_{5}\right)^{-}\right), \mathbf{9}\left(\mathrm{R}, \mathrm{R}=-\mathrm{CH}_{2} \mathrm{CH}_{2} \mathrm{OCH}_{2} \mathrm{CH}_{2^{-}}\right)$<smiles>O=C(Cl)[C]1CC=CC[C@H]1C(=O)Cl</smiles>

(1) $\mathrm{Me}\left(\mathrm{OCH}_{2} \mathrm{CH}_{2}\right)_{3} \mathrm{OH}, \mathrm{Py}$

(2) $\mathrm{m}$-CPBA

(3) piperidine, $\mathrm{H}_{2} \mathrm{O}$, iPrOH<smiles>COCCOCCOCCOC(=O)[C@@H]1C[C@H](O)[C@H](N2CCCCC2)C[C@H]1C(=O)OCCOCCOCCOC</smiles><smiles>O=C(Cl)[C@]1CC=CC[C@]1C(=O)Cl</smiles>

(1) $\mathrm{H}\left(\mathrm{OCH}_{2} \mathrm{CH}_{2}\right)_{4} \mathrm{OH}$, Py

(2) m-CPBA

(3) piperidine, $\mathrm{H}_{2} \mathrm{O}$, iPrOH<smiles>O=C(OCCOCCOCCOCCOC(=O)N1CCCCC1)[C@@H]1C[C@H](N2CCCCC2)[C@H](O)C[C@H]1O</smiles>

11

\section{Scheme 4}

The position of the equilibrium $\mathbf{3 A} \rightleftarrows 3 \mathbf{B}$ (Scheme 3 ) was used as an indicator of the changes in intramolecular interactions. The conformer populations $\left(n_{A}, n_{B}\right)$ and the free energy differences between conformers $\left(\Delta \mathrm{G}_{\mathbf{B}-\mathrm{A}}\right)$ were estimated by ${ }^{1} \mathrm{H}$ NMR measurements in various solutions (Table 1). The conformer populations were determined using Eliel's equation ${ }^{43}$ for signal widths $\left(W=\Sigma J_{H H}\right)$ of the cyclohexane protons $\mathrm{H}_{1}, \mathrm{H}_{2}, \mathrm{H}_{4}$ and $\mathrm{H}_{5}$, measured as a distance between terminal peaks of a multiplet: $\boldsymbol{W}_{\text {observed }}=\boldsymbol{W}_{A} \boldsymbol{n}_{A}+\boldsymbol{W}_{\boldsymbol{B}} \boldsymbol{n}_{\boldsymbol{B}}$. The signal widths for individual conformers were estimated from measurements for compounds 5-11 and for closely related cyclohexane derivatives with completely biased conformational equilibrium: ${ }^{16-20,23,44,45}$ $W_{A}=25.7 \mathrm{~Hz}\left(25.0 \mathrm{~Hz}\right.$ for 5, 7, 9) and $W_{B}=9 \mathrm{~Hz}$ for $\mathrm{H}_{\mathrm{OH}} ; W_{A}=26.6 \mathrm{~Hz}(25.5 \mathrm{~Hz}$ for 5, 7, 9) and $W_{B}=10 \mathrm{~Hz}$ for $\mathrm{H}_{\mathrm{NR} 2}$; and $W_{A}=9 \mathrm{~Hz}$ and $W_{B}=30 \mathrm{~Hz}$ for $\mathrm{H}_{\mathrm{COOR}}$. The more accurate estimations were usually obtained from the data for $\mathrm{H}_{\mathrm{OH}}\left(\mathrm{H}_{5}\right)$ signal. We did not use the averaged chemical shifts for the equilibrium estimations because of their general sensitivity to temperature, to the nature of a solvent, the complex formation, additives, etc. 
Table 1. ${ }^{1} \mathrm{H}$ NMR data $(400 \mathrm{MHz})$ and conformational parameters

\begin{tabular}{|c|c|c|c|c|c|c|c|c|c|c|}
\hline \multirow{2}{*}{$\begin{array}{l}\text { Compound, solvent, } \\
\text { and additives }{ }^{\text {a) }}\end{array}$} & \multicolumn{2}{|c|}{$\mathrm{H}_{\mathrm{OH}}$} & \multicolumn{2}{|c|}{$\mathrm{H}_{\mathrm{N}}$} & \multicolumn{2}{|c|}{$\mathrm{H}_{\mathrm{COOR}(2)}$} & \multicolumn{2}{|c|}{$\mathrm{H}_{\mathrm{COOR}(1)}$} & \multirow{2}{*}{$\begin{array}{c}\mathrm{n}_{\mathrm{A}} \\
\%\end{array}$} & \multirow{2}{*}{$\begin{array}{l}\Delta \mathrm{G}_{\mathrm{B}-\mathrm{A}}, \\
\mathrm{kJ} / \mathrm{mol}\end{array}$} \\
\hline & $\delta$ & $\mathrm{W}, \mathrm{Hz}$ & $\delta$ & $\mathrm{W}, \mathrm{Hz}$ & $\delta$ & $\mathrm{W}, \mathrm{Hz}$ & $\delta$ & $\mathrm{W}, \mathrm{Hz}$ & & \\
\hline 5 in $\mathrm{C}_{6} \mathrm{D}_{12}$ & 3.36 & 24.5 & 2.2 & b) & 3.16 & $<17$ & 3.16 & $<17$ & $>95$ & $>7.5$ \\
\hline 5 in $\mathrm{CDCl}_{3}$ & 3.39 & 24.9 & 2.2 & b) & 3.2 & 11 & 3.2 & 11 & $>95$ & $>7.5$ \\
\hline 5 in $\mathrm{CD}_{3} \mathrm{OD}$ & 3.93 & 14.9 & 2.16 & 15.1 & 3.08 & 21.8 & 2.99 & 21.1 & 35 & -1.5 \\
\hline 6 in $\mathrm{C}_{6} \mathrm{D}_{12}-\mathrm{CCl}_{4}$ & 3.21 & 25.5 & 2.4 & b) & 3.13 & 11 & 3.09 & 11 & $\sim 100$ & $>9$ \\
\hline 6 in $\mathrm{CDCl}_{3}$ & 3.41 & 25.6 & 2.5 & b) & 3.25 & 11 & 3.21 & 11 & $\sim 100$ & $>9$ \\
\hline 6 in $\mathrm{CD}_{3} \mathrm{OD}$ & 3.71 & 21.0 & 2.5 & b) & 3.2 & $<23^{\text {b) }}$ & 3.2 & $<23^{\text {b) }}$ & 72 & 2.3 \\
\hline$+\mathrm{AcOH}$ & 3.89 & 25.7 & 3 & b) & 3.75 & $(7)^{c)}$ & 3.75 & $(7)^{c)}$ & $\sim 100$ & $>9$ \\
\hline 7 in $\mathrm{CDCl}_{3}$ & 3.72 & 16.8 & 2.36 & 16.9 & 3.1 & $<23$ & 3.1 & $<23$ & 44 & -0.6 \\
\hline 7 in $\mathrm{CD}_{3} \mathrm{OD}$ & 4.02 & 10.6 & 2.30 & 10 & 3.01 & 25.3 & 2.98 & 26.4 & 10 & -5.4 \\
\hline$+\mathrm{AcOH}$ & 3.84 & 22.4 & 3.16 & 23.0 & 3.3 & b) & 3.3 & b) & 85 & 4.3 \\
\hline$+\mathrm{CF}_{3} \mathrm{COOH}$ & 3.80 & 24.1 & 3.3 & b) & 3.3 & b) & 3.3 & b) & 94 & 7 \\
\hline 8 in $\mathrm{C}_{6} \mathrm{D}_{12}-\mathrm{CCl}_{4}$ & 3.35 & 24.8 & 2.22 & 26.5 & 3.2 & b) & 3.2 & b) & $>95$ & $>7.5$ \\
\hline 8 in $\mathrm{CDCl}_{3}$ & 3.38 & 25.5 & 2.2 & b) & 3.20 & $(10)^{c)}$ & 3.20 & $(10)^{\mathrm{c})}$ & $\sim 100$ & $>9$ \\
\hline 8 in $\mathrm{CD}_{3} \mathrm{OD}$ & 3.81 & 18.4 & 2.23 & 18.7 & 3.12 & 17.7 & 3.05 & 17.2 & 56 & 0.6 \\
\hline$+\mathrm{AcOH}$ & 3.85 & 25.5 & 3.11 & 26.4 & 3.36 & $(12)^{c}$ & 3.3 & b) & $\sim 100$ & $>9$ \\
\hline$+\mathrm{KI}$ & 3.82 & 18.5 & 2.23 & 18.6 & 3.12 & 17.5 & 3.07 & 17.1 & 56 & 0.6 \\
\hline 9 in $\mathrm{CDCl}_{3}$ & 3.48 & 24.5 & 2.25 & 24.6 & 3.24 & $(13)^{c}$ & 3.24 & $(13)^{c)}$ & $>95$ & $>7.5^{20}$ \\
\hline 9 in $\mathrm{CD}_{3} \mathrm{OD}$ & 3.98 & 14.4 & 2.23 & 14.8 & 3.07 & 22.4 & 2.97 & 21.6 & 35 & $-1.5^{20}$ \\
\hline 9 in $\left(\mathrm{CD}_{3}\right)_{2} \mathrm{SO}$ & 3.94 & $(11)^{\mathrm{c})}$ & 2.12 & $(16)^{c)}$ & 2.91 & 25.2 & 2.75 & 24.5 & 25 & $-2.7^{20}$ \\
\hline 10 in $\mathrm{CDCl}_{3}$ & 3.47 & 25.5 & 2.33 & 26 & 3.3 & b) & 3.3 & b) & $>95$ & $>7.5$ \\
\hline 10 in $\mathrm{CD}_{3} \mathrm{OD}$ & 3.79 & 20.1 & 2.29 & 20.5 & 3.22 & $18^{\mathrm{b})}$ & 3.17 & $18^{\mathrm{b})}$ & 65 & $1.5^{23}$ \\
\hline$+\mathrm{AcOH}$ & 3.89 & 25.7 & 3.12 & 26.6 & 3.4 & b) & 3.4 & b) & $\sim 100$ & $>9^{23}$ \\
\hline$+\mathrm{KI}$ & 3.92 & 17.1 & 2.3 & c) & 3.19 & $(19)^{c)}$ & 3.13 & b) & 49 & $-0.1^{23}$ \\
\hline$+\mathrm{KI}+\mathrm{AcOH}$ & 3.95 & 25.7 & 3.20 & 26.6 & 3.4 & b) & 3.4 & b) & $\sim 100$ & $>9^{23}$ \\
\hline 11 in $\mathrm{CD}_{3} \mathrm{OD}$ & 4.02 & 14.7 & 2.29 & 14.6 & 3.20 & 22.1 & 3.09 & 21.3 & 35 & $-1.5^{23}$ \\
\hline$+\mathrm{AcOH}$ & 4.01 & 25.4 & 3.20 & $\sim 25^{\mathrm{c})}$ & 3.4 & b) & 3.4 & b) & $\sim 100$ & $>9^{23}$ \\
\hline$+\mathrm{KI}$ & 4.12 & 12 & 2.27 & c) & 3.2 & b) & 3.2 & b) & 20 & $-3.5^{23}$ \\
\hline$+\mathrm{KI}+\mathrm{AcOH}$ & 4.01 & 25.1 & 3.22 & 26 & 3.45 & 11 & 3.40 & 11 & 95 & $7.5^{23}$ \\
\hline
\end{tabular}

a) Acid and/or salt were added in large excess.

b) Partially or completely overlapped with other signals.

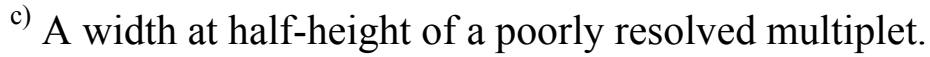

In accordance with the preliminary observations, ${ }^{20,23}$ all the studied molecules, except the pyrrolidinyl derivative 7, strongly prefer the conformation 2A (Scheme 2) in nonpolar solvents $\mathrm{C}_{6} \mathrm{D}_{12}-\mathrm{CCl}_{4}$ (1:1) and $\mathrm{CDCl}_{3}$. The equilibrium switches to conformation $2 \mathbf{B}$ in $\mathrm{CD}_{3} \mathrm{OD}$. 
Apparently, methanol effectively disrupts the intramolecular $\mathrm{OH} \cdots \mathrm{N}$ hydrogen bond that stabilizes 2A. The addition of excess acetic acid causes an opposite switch to conformation $\mathbf{A}$, even in methanol solutions (3A, Scheme 3). Trifloroacetic acid produces a stronger effect. The power of this conformational $\mathrm{pH}$-trigger has been estimated from the measurements for compound 7 as $\geq 12 \mathrm{~kJ} / \mathrm{mol}$ (Table 1). Hydrogen bonds of both $\mathrm{OH} \cdots \mathrm{N}$ and $\mathrm{O} \cdots \mathrm{H}-\mathrm{N}^{+}$types are known to convert a chair ring into a twist conformation in trans-aminohydroxy steroids ${ }^{46,47}$ and some other conformationally locked structures. ${ }^{42,44}$ This acid-induced twisting of six-membered cycles indicates that the actual power of such triggers may be well above $20 \mathrm{~kJ} / \mathrm{mol}$. The latter fact also points out that a relative flexibility of cyclohexane ring sets a natural limit to the effective power of conformational tools (levers, locks, counterbalances) in such systems. If the power applied to both ends of the system exceeds the energy difference between the chair and twist-forms of cyclohexane $\left(23-26 \mathrm{~kJ} / \mathrm{mol}^{48}\right)$, then the ring may be screwed (for the relevant discussion see $\left.{ }^{13,17,27,42,44,49}\right)$.

Similar to the simpler model $\mathbf{8}$, the conformation $\mathbf{A}$ is somewhat preferred for the podand $\mathbf{1 0}$ (Table 1, Scheme 5). ${ }^{23}$ The conformation $\mathbf{1 0 A}$ is slightly more predominant than $\mathbf{8 A}$ in methanol solution. By contrast, the crown ether 11 prefers the conformation 11B with both ester groups equatorial (Table 1, Scheme 6), which can be attributed to a 'contraction effect' ${ }^{\text {4-7,9,13,15-18,21,23 }}$ of the macrocycle.

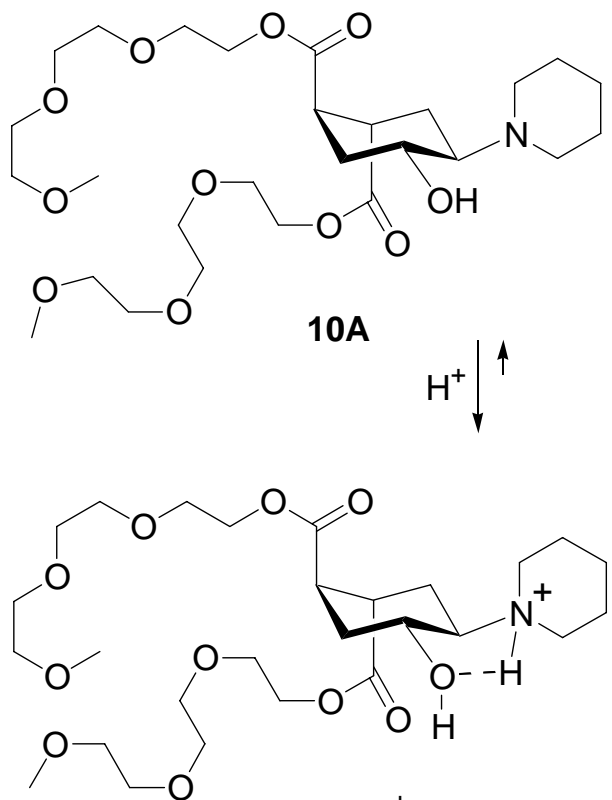

$10 \mathrm{~A}^{\cdot} \mathrm{H}^{+}$
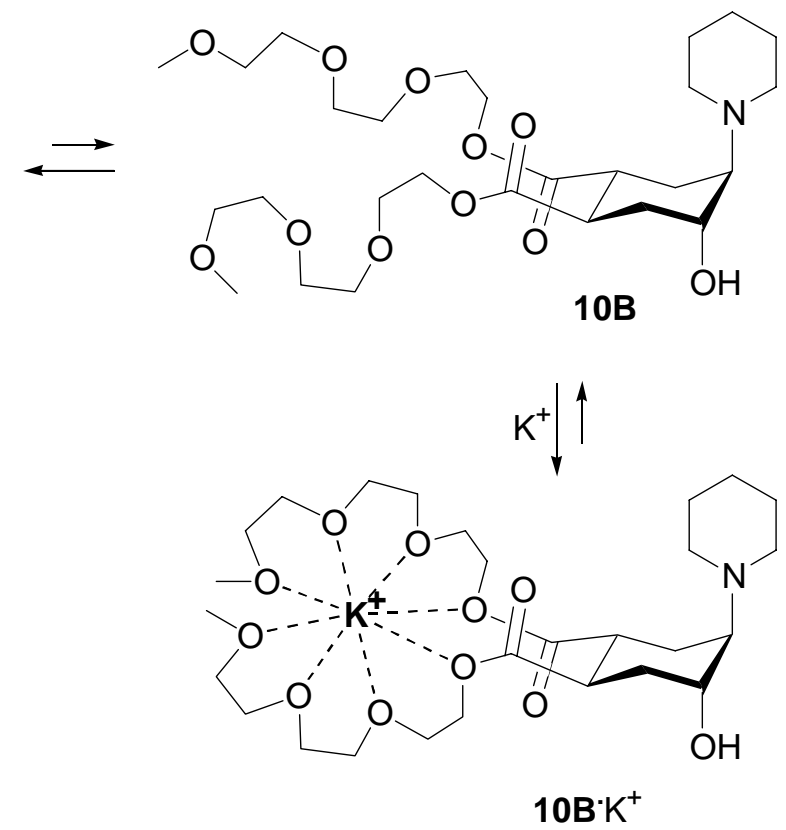

\section{Scheme 5}


As all other studied structures, both ionophores demonstrate a dramatic switch to conformation A $\left(\mathbf{A} \cdot \mathrm{H}^{+}\right)$with excess acid (Table 1, Schemes 5,6). The power of this conformational trigger has been estimated from the measurements for compound $\mathbf{1 1}$ as $\geq 10.5$ $\mathrm{kJ} / \mathrm{mol}$.

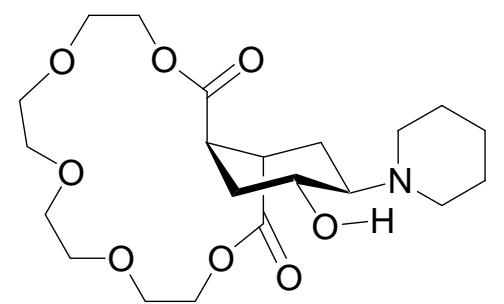

$11 \mathrm{~A}$

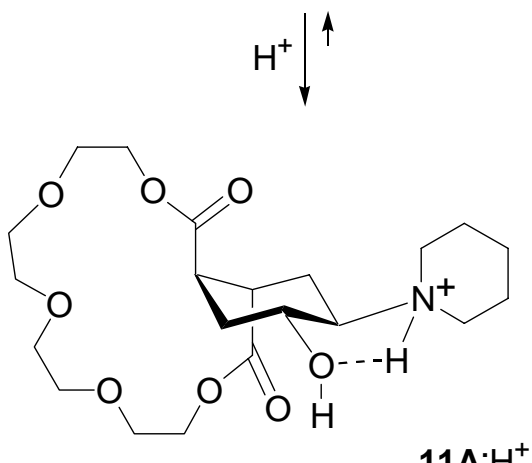

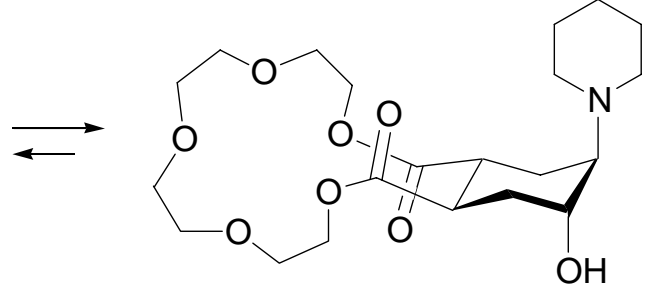

11B

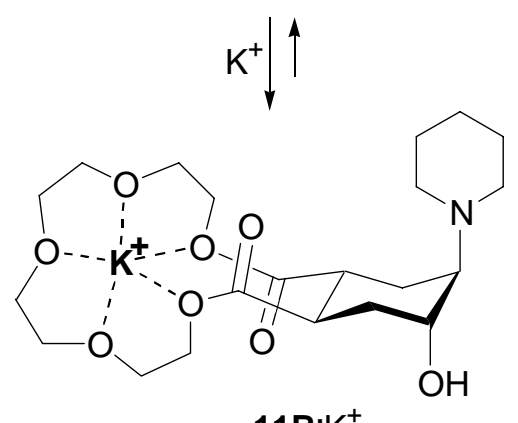

$11 \mathrm{~B} \cdot \mathrm{K}^{+}$

\section{Scheme 6}

The macrocycle in $\mathbf{1 1}$ and the polyether chains in $\mathbf{1 0}$ should be able to complex metal ions, thus providing a second binding site required for modelling of a negative allosteric effect. The necessary geometrical arrangement for such complexation can be achieved only in conformations 10B and 11B. When methanolic solutions of $\mathbf{1 0}$ or $\mathbf{1 1}$ were saturated with KI, the conformational equilibria were shifted to these $\mathbf{B}$ conformations (Table 1, Schemes 5,6) with a relatively small power of approximately $1.5-2 \mathrm{~kJ} / \mathrm{mol}^{23}$ Addition of excess acetic acid to these solutions completely switched the equilibrium back to conformations 10A and 11A. By contrast, the conformational equilibrium for the related non-complexing compound $\mathbf{8}$ was indifferent to the addition of potassium salt (Table 1).

There is a substantial difference in positions of conformational equilibria for similar structures 5-9 with different $\mathrm{NR}_{2}$ groups. The preference for conformation $\mathbf{A}\left(\Delta \mathrm{G}_{\mathrm{B}-\mathrm{A}}\right.$, in $\left.\mathrm{CD}_{3} \mathrm{OD}\right)$ decreases in order (Table 1):

$\mathrm{Et}_{2} \mathrm{~N}(2.3 \mathrm{~kJ} / \mathrm{mol})>$ piperidyl $(0.6)>\mathrm{Me}_{2} \mathrm{~N}(-1.5) \sim$ morpholyl (-1.5) $>$ pyrrolidyl (-5.4) 
This order shows poor correlation with the effective bulkiness of $\mathrm{NR}_{2}$ groups, i.e. their Avalues. As estimated by simple calculations (PCMODEL molecular mechanics ${ }^{50}$ ) for $\mathrm{R}_{2} \mathrm{~N}-$ cyclohexanes with no account for solvent effects, they are:

$\mathrm{Et}_{2} \mathrm{~N}(6.7 \mathrm{~kJ} / \mathrm{mol})>\operatorname{piperidyl}(5.1)>\operatorname{pyrrolidyl}(4.3) \sim \mathrm{Me}_{2} \mathrm{~N}(4.2) \geq \operatorname{morpholyl}(3.6)$

However, the similar PCMODEL calculations for trans-2- $\mathrm{R}_{2} \mathrm{~N}$-cyclohexanols, which included an intramolecular $\mathrm{OH} \cdots \mathrm{N}$ hydrogen bond, produced the preference for the diequatorial conformation (equivalent to A) that qualitatively parallels the experimental order for compounds 5-9:

$\mathrm{Et}_{2} \mathrm{~N}(17.5 \mathrm{~kJ} / \mathrm{mol}) \geq$ piperidyl (17.2) $>\mathrm{Me}_{2} \mathrm{~N}(15.2) \geq$ morpholyl (14.9) $>$ pyrrolidyl (8.5)

Apparently, the geometrical requirements of the intramolecular hydrogen bond play an important role. The formation of hydrogen bond of $\mathrm{OH} \cdots \mathrm{N}$, or $\mathrm{O} \cdots \mathrm{H}-\mathrm{N}^{+}$type forces $\mathrm{NR}_{2}$ group to adopt a conformation, which is different from its optimum conformation. In other words, the optimum conformations of different $\mathrm{NR}_{2}$ groups are not equally suited to the formation of hydrogen bond with the vicinal $\mathrm{OH}$ group. The magnitude of this additional strain depends on the structure of $\mathrm{NR}_{2}$. A similar observation was made for trans-2-amino- and trans-2dimethylamino-cyclohexanols, ${ }^{49}$ where the net gauche-attraction between $\mathrm{OH}$ and $\mathrm{NR}_{2}$ (in $\left.\mathrm{C}_{2} \mathrm{Cl}_{4}\right)$ was stronger for $\mathrm{NH}_{2}$ than for the more basic $\mathrm{NMe}_{2}$ group $(3.8 \mathrm{~kJ} / \mathrm{mol}$ and $2.5 \mathrm{~kJ} / \mathrm{mol}$, respectively).

However, if the intramolecular hydrogen bond is not included, and the $\mathrm{OH}$ group points away from $\mathrm{NR}_{2}$ group (which may be the case in methanol solution), the calculated preference for the diequatorial conformation A for trans-2- $\mathrm{R}_{2} \mathrm{~N}$-cyclohexanols still parallels the experimental order for 5-9:

$\mathrm{Et}_{2} \mathrm{~N}(10.3 \mathrm{~kJ} / \mathrm{mol})>\operatorname{piperidyl}(8.9)>\operatorname{morpholyl}(8.3) \geq \mathrm{Me}_{2} \mathrm{~N}(7.5)>\operatorname{pyrrolidyl}(0.3)$

Evidently, the steric restrictions imposed by the vicinal oxygen may be sufficient to force the equatorial dialkylamino group into non-optimal position thus affecting the conformational preferences of trans-2- $\mathrm{R}_{2} \mathrm{~N}$-cyclohexanols.

\section{Conclusions}

The results of the present study prove that the trans-2-aminocyclohexanol moiety can be used as a conformational $\mathrm{pH}$-trigger for the control of the complex formation by various crown ethers and podands via switching of their preferred conformation. The strong conformational coupling of two different binding sites in compounds like $\mathbf{1 0}$ or $\mathbf{1 1}$ should allow the development of new 
heterotropic allosteric systems with high negative cooperativity, which may be especially useful for a selective membrane or drug transport. The variation of $\mathrm{NR}_{2}$ groups allows a broad tuning of the conformational equilibrium, and thus of the complexing ability of these allosteric ionophores. In addition, the basicity of amino functions could be tuned for a response within a narrow $\mathrm{pH}$ range, in which such a switchable system could then liberate or bind drugs or toxic compounds.

\section{Experimental Section}

General Procedures. ${ }^{1} \mathrm{H}$ NMR spectra were recorded on Varian VXR-400 (400 MHz) instrument. ${ }^{13} \mathrm{C}$ NMR spectra were recorded on Varian Mercury-300 (75.5 MHz) instrument. The signals were assigned using COSY, HETCOR and homonuclear spin-spin decoupling techniques.

Exact mass measurements were performed on the JEOL LCMate double-focusing mass spectrometer (Peabody, MA, USA) equipped with atmospheric pressure chemical ionization source at a resolving power of 5000 with polyethyleneglycol as an internal reference. The MS/MS spectra were obtained using the Varian 1200L triple quadrupole mass spectrometer (Walnut Creek, CA, USA) with electrospray source.

The compounds $\mathbf{4},{ }^{20,30} \mathbf{9},{ }^{20} \mathbf{1 0},{ }^{23} \mathbf{1 1},{ }^{23}$ and their precursors ${ }^{14,15}$ have been described previously.

\section{General procedure for the reaction of epoxides with amines}

Epoxide $4(0.73 \mathrm{~g}, 3 \mathrm{mmol})$ and amine $(10 \mathrm{mmol})$ were stirred in a mixture of $1 \mathrm{ml}$ water and $1 \mathrm{ml}$ isopropanol for $15 \mathrm{~h}$ at r.t. The reaction mixture was evaporated in vacuo, and the product was purified by column chromatography (silica gel, ethyl acetate). A commercial $40 \%$ aqueous dimethylamine was used for the preparation of compound 5. All products were colorless viscous liquids.

trans-1,2-Bis(ethoxycarbonyl)-cis-4-hydroxy-trans-5-dimethylaminocyclohexane (5). Yield: 34\%. ${ }^{1} \mathrm{H}$ NMR (400 MHz, $\left.\mathrm{CD}_{3} \mathrm{OD}\right): \delta 1.235\left(\mathrm{t}, 3 \mathrm{H}, \mathrm{CH}_{3}\right), 1.240\left(\mathrm{t}, 3 \mathrm{H}, \mathrm{CH}_{3}\right), 1.77\left(\mathrm{ddd}, \mathrm{H}^{3}\right.$ ), $1.83\left(\mathrm{ddd}, \mathrm{H}^{6}\right), 2.0\left(\mathrm{~m}, \mathrm{H}^{6}\right), 2.03\left(\mathrm{~m}, \mathrm{H}^{3}\right), 2.16\left(\mathrm{dt}, \mathrm{H}^{5}\right), 2.27\left(\mathrm{~s}, 6 \mathrm{H}, \mathrm{NCH}_{3}\right), 2.99\left(\mathrm{dt}, \mathrm{H}^{1}\right), 3.08$ $\left(\mathrm{dt}, \mathrm{H}^{2}\right), 3.93\left(\mathrm{dt}, \mathrm{H}^{4}\right), 4.1\left(\mathrm{~m}, 4 \mathrm{H}, \mathrm{OCH}_{2} \mathrm{Me}\right), 4.76(\mathrm{~s}, \mathrm{OH}) .{ }^{13} \mathrm{C} \mathrm{NMR}\left(75 \mathrm{MHz}, \mathrm{CD}_{3} \mathrm{OD}\right): \delta$ 175.82, $175.66(\mathrm{C}=\mathrm{O}), 66.79(\mathrm{C} 5), 66.36(\mathrm{C} 4), 62.05,61.99\left(\mathrm{OCH}_{2} \mathrm{Me}\right), 42.19\left(\mathrm{CH}_{3} \mathrm{~N}\right), 41.18$ (C2), 41.11 (C1), 32.37 (C3), 24.50 (C6), $14.52\left(\mathrm{CH}_{3}\right) . \mathrm{MS} / \mathrm{MS} \mathrm{m} / z$ (rel. intensity): 72.0 (21), 79.2 (12), 95.4 (50), 99.3 (16), 113.3 (23), 123.2 (54), 141.4 (28), 150.7 (27), 169.1 (100), 196.7 (51), 242.3 (15), $270.3(18), 288.2\left([\mathrm{M}+\mathrm{H}]^{+}, 14\right)$. HRMS: $\mathrm{C}_{14} \mathrm{H}_{25} \mathrm{NO}_{5}$ requires $[\mathrm{M}+\mathrm{H}]^{+} 288.1811$, found 288.1855 .

trans-1,2-Bis(ethoxycarbonyl)-cis-4-hydroxy-trans-5-diethylaminocyclohexane (6). Yield: 41\%. ${ }^{1} \mathrm{H}$ NMR (300 MHz, CD $\left.\mathrm{OD}\right): \delta 1.04\left(\mathrm{t}, 6 \mathrm{H}, \mathrm{CH}_{3}\right), 1.25\left(\mathrm{t}, 3 \mathrm{H}, \mathrm{CH}_{3}\right), 1.26\left(\mathrm{t}, 3 \mathrm{H}, \mathrm{CH}_{3}\right)$, $1.62\left(\mathrm{ddd}, \mathrm{H}^{3 \mathrm{a}}\right), 1.66\left(\mathrm{ddd}, \mathrm{H}^{6 \mathrm{a}}\right), 2.11\left(\mathrm{~m}, \mathrm{H}^{6 \mathrm{e}}\right), 2.25\left(\mathrm{~m}, \mathrm{H}^{3 \mathrm{e}}\right), 2.5\left(\mathrm{~m}, 3 \mathrm{H}, \mathrm{CH}_{2} \mathrm{~N}+\mathrm{H}^{5}\right), 2.65(\mathrm{~m}$, $\left.2 \mathrm{H}, \mathrm{CH}_{2} \mathrm{~N}\right), 3.16\left(\mathrm{~m}, \mathrm{H}^{1}+\mathrm{H}^{2}\right), 3.68\left(\mathrm{dt}, \mathrm{H}^{4}\right), 4.15\left(\mathrm{~m}, 4 \mathrm{H}, \mathrm{OCH}_{2} \mathrm{Me}\right) .4 .85(\mathrm{~s}, \mathrm{OH}) .{ }^{13} \mathrm{C} \mathrm{NMR}$ 
(75 MHz, $\left.\mathrm{CD}_{3} \mathrm{OD}\right): \delta 175.51,175.39(\mathrm{C}=\mathrm{O}), 66.91(\mathrm{C} 4), 62.15(\mathrm{C} 5), 62.06,62.03\left(\mathrm{OCH}_{2} \mathrm{Me}\right)$, $44.24\left(\mathrm{CH}_{2} \mathrm{~N}\right), 41.95(\mathrm{C} 1 / 2), 41.54(\mathrm{C} 2 / 1), 32.42(\mathrm{C} 3), 23.95(\mathrm{C} 6), 14.57,14.53\left(\mathrm{OCH}_{2} \mathrm{CH}_{3}\right)$, $13.64\left(\mathrm{NCH}_{2} \mathrm{CH}_{3}\right)$. MS/MS m/z (rel. intensity): 73.7 (11), 95.3 (44), 99.8 (20), 113.1 (19), 123.2 (27), 141.3 (30), 151.1 (17), 169.4 (100), 196.9 (27), 224.4 (16), 270.4 (15), 298.3 (17), 316.3 $\left([\mathrm{M}+\mathrm{H}]^{+}, 27\right)$. HRMS: $\mathrm{C}_{16} \mathrm{H}_{29} \mathrm{NO}_{5}$ requires $[\mathrm{M}+\mathrm{H}]^{+} 316.2124$, found 316.2157 .

trans-1,2-Bis(ethoxycarbonyl)-cis-4-hydroxy-trans-5-pyrrolidylcyclohexane (7). Yield: 77\%. ${ }^{1} \mathrm{H}$ NMR (400 MHz, CD $\left.{ }_{3} \mathrm{OD}\right): \delta 1.225\left(\mathrm{t}, 3 \mathrm{H}, \mathrm{CH}_{3}\right), 1.230\left(\mathrm{t}, 3 \mathrm{H}, \mathrm{CH}_{3}\right), 1.84\left(\mathrm{~m}, 4 \mathrm{H}, \mathrm{CH}_{2}\right.$ pyrrolidyl), 1.9-2.05 (m, 4H, $\left.\mathrm{CH}_{2}\right), 2.30\left(\mathrm{~m}, \mathrm{H}^{5}\right), 2.62\left(\mathrm{~m}, 4 \mathrm{H}, \mathrm{CH}_{2} \mathrm{~N}\right), 2.98\left(\mathrm{dt}, \mathrm{H}^{1}\right), 3.01(\mathrm{dt}$, $\mathrm{H}^{2}$ ), 4.02 (br.q, $\mathrm{H}^{4}$ ), 4.1 (m, 4H, $\left.\mathrm{OCH}_{2} \mathrm{Me}\right), 4.88(\mathrm{~s}, \mathrm{OH}) .{ }^{13} \mathrm{C} \mathrm{NMR}\left(75 \mathrm{MHz}, \mathrm{CD}_{3} \mathrm{OD}\right): \delta$ 177.05, $177.00(\mathrm{C}=\mathrm{O}), 67.36(\mathrm{C} 4), 65.82(\mathrm{C} 5), 61.69\left(\mathrm{OCH}_{2} \mathrm{Me}\right), 52.71\left(\mathrm{CH}_{2} \mathrm{~N}\right), 40.61(\mathrm{C} 1)$, 40.50 (C2), 31.45 (C3), 28.24 (C6), $24.33\left(\mathrm{CH}_{2}\right.$ pyrrolidyl), $14.51\left(\mathrm{CH}_{3}\right) . \mathrm{MS} / \mathrm{MS} \mathrm{m} / z$ (rel. intensity): 70.6 (18), 79.2 (12), 96.5 (80), 108.2 (10), 113.0 (21), 123.3 (30), 141.2 (31), 149.8 (35), 169.3 (100), 196.5 (39), 222.4 (38), 240.3 (22), 268.3 (40), 296.3 (30), $314.3\left([\mathrm{M}+\mathrm{H}]^{+}, 38\right)$. HRMS: $\mathrm{C}_{16} \mathrm{H}_{27} \mathrm{NO}_{5}$ requires $[\mathrm{M}+\mathrm{H}]^{+} 314.1967$, found 314.1957 .

trans-1,2-Bis(ethoxycarbonyl)-cis-4-hydroxy-trans-5-piperidylcyclohexane (8). Yield: 56\%. ${ }^{1} \mathrm{H}$ NMR (400 MHz, $\left.\mathrm{CD}_{3} \mathrm{OD}\right): \delta 1.24\left(\mathrm{t}, 6 \mathrm{H}, \mathrm{CH}_{3}\right), 1.44\left(\mathrm{~m}, 2 \mathrm{H}, \mathrm{CH}_{2}\right.$ piperidyl), $1.57(\mathrm{~m}, 4 \mathrm{H}$, $\mathrm{CH}_{2}$ piperidyl), $1.69\left(\mathrm{ddd}, \mathrm{H}^{3}\right), 1.76\left(\mathrm{ddd}, \mathrm{H}^{6}\right), 2.08\left(\mathrm{dddd}, \mathrm{H}^{6}\right), 2.16\left(\mathrm{dddd}, \mathrm{H}^{3}\right), 2.23\left(\mathrm{dt}, \mathrm{H}^{5}\right)$, $2.42\left(\mathrm{~m}, 2 \mathrm{H}, \mathrm{CH}_{2} \mathrm{~N}\right), 2.59\left(\mathrm{~m}, 2 \mathrm{H}, \mathrm{CH}_{2} \mathrm{~N}\right), 3.05\left(\mathrm{~m}, \mathrm{H}^{1}\right), 3.12\left(\mathrm{~m}, \mathrm{H}^{2}\right), 3.81\left(\mathrm{dt}, \mathrm{H}^{4}\right), 4.14(\mathrm{~m}, 4 \mathrm{H}$, $\left.\mathrm{OCH}_{2} \mathrm{Me}\right), 4.87(\mathrm{~s}, \mathrm{OH}) .{ }^{13} \mathrm{C} \mathrm{NMR}\left(75 \mathrm{MHz}, \mathrm{CD}_{3} \mathrm{OD}\right): \delta 175.90,175.75(\mathrm{C}=\mathrm{O}), 66.46(\mathrm{C} 4)$, $66.41(\mathrm{C} 5), 61.94\left(\mathrm{OCH}_{2} \mathrm{Me}\right), 51.72\left(\mathrm{CH}_{2} \mathrm{~N}\right), 41.60(\mathrm{C} 1), 41.23(\mathrm{C} 2), 32.36(\mathrm{C} 3), 27.45\left(\mathrm{CH}_{2}\right.$ piperidyl), $25.85\left(\mathrm{CH}_{2}\right.$ piperidyl), 24.20 (C6), 14.56, $14.53\left(\mathrm{CH}_{3}\right) . \mathrm{MS} / \mathrm{MS} \mathrm{m} / z$ (rel. intensity): 85.3 (16), 95.5 (54), 99.5 (12), 112.8 (35), 123.1 (42), 141.5 (28), 151.2 (10), 169.6 (100), 197.2 (16), 208.6 (23), 236.5 (24), 254.4 (16), 282.6 (34), 310.5 (35), $328.3\left([\mathrm{M}+\mathrm{H}]^{+}, 61\right)$. HRMS: $\mathrm{C}_{17} \mathrm{H}_{29} \mathrm{NO}_{5}$ requires $[\mathrm{M}+\mathrm{H}]^{+} 328.2124$, found 328.2146 .

trans-1,2-Bis(ethoxycarbonyl)-cis-4-hydroxy-trans-5-morpholylcyclohexane $\quad$ (9). ${ }^{20}$ Yield: 46\%. ${ }^{1} \mathrm{H}$ NMR (300 MHz, $\left.\mathrm{CD}_{3} \mathrm{OD}\right): \delta 1.232\left(\mathrm{t}, 3 \mathrm{H}, \mathrm{CH}_{3}\right), 1.234\left(\mathrm{t}, 3 \mathrm{H}, \mathrm{CH}_{3}\right), 1.77\left(\mathrm{ddd}, \mathrm{H}^{3}\right.$ ), $1.87\left(\mathrm{ddd}, \mathrm{H}^{6}\right), 1.99\left(\mathrm{dt}, \mathrm{H}^{6}\right), 2.03\left(\mathrm{ddd}, \mathrm{H}^{3}\right), 2.23\left(\mathrm{dt}, \mathrm{H}^{5}\right), 2.48\left(\mathrm{~m}, 2 \mathrm{H} \mathrm{CH} \mathrm{CH}_{2} \mathrm{~N}\right), 2.57(\mathrm{~m}, 2 \mathrm{H}$ $\left.\mathrm{CH}_{2} \mathrm{~N}\right), 2.97\left(\mathrm{dt}, \mathrm{H}^{1}\right), 3.07\left(\mathrm{dt}, \mathrm{H}^{2}\right), 3.69\left(\mathrm{t}, 4 \mathrm{H}, \mathrm{OCH}_{2}\right.$ morpholyl), $3.98\left(\mathrm{dt}, \mathrm{H}^{4}\right), 4.12(\mathrm{~m}, 4 \mathrm{H}$, $\left.\mathrm{OCH}_{2} \mathrm{Me}\right), 4.85(\mathrm{~s}, \mathrm{OH}) .{ }^{13} \mathrm{C} \mathrm{NMR}\left(75 \mathrm{MHz}, \mathrm{CD}_{3} \mathrm{OD}\right): \delta 176.36,176.14(\mathrm{C}=\mathrm{O}), 68.31\left(\mathrm{OCH}_{2}\right.$ morpholyl), 65.68 (C4), 65.41 (C5), 61.86, $61.84\left(\mathrm{OCH}_{2} \mathrm{Me}\right), 51.49\left(\mathrm{CH}_{2} \mathrm{~N}\right), 41.01(\mathrm{C} 1), 40.88$ (C2), 31.87 (C3), 24.74 (C6), $14.53\left(\mathrm{CH}_{3}\right)$. MS/MS m/z (rel. intensity): 87.8 (16), 95.3 (43), 99.5 (10), 113.8 (45), 123.4 (34), 141.2 (27), 151.3 (19), 169.2 (100), 197.4 (21), 210.3 (20), 238.3 (43), 284.3 (17), $312.3(24), 330.2\left([\mathrm{M}+\mathrm{H}]^{+}, 22\right)$. HRMS: $\mathrm{C}_{16} \mathrm{H}_{27} \mathrm{NO}_{6}$ requires $[\mathrm{M}+\mathrm{H}]^{+} 330.1917$, found 330.1898 .

trans-1,2-Bis(3,6,9-trioxadecyloxycarbonyl)-cis-4-hydroxy-trans-5-piperidylcyclohexane (10). Yield: 44\%. ${ }^{1} \mathrm{H}$ NMR (400 MHz, $\left.\mathrm{CD}_{3} \mathrm{OD}\right): \delta 1.47\left(\mathrm{~m}, 2 \mathrm{H}, \mathrm{CH}_{2}\right.$ piperidyl), $1.59(\mathrm{~m}, 4 \mathrm{H}$, $\mathrm{CH}_{2}$ piperidyl), 1.69 (ddd, $\left.\mathrm{H}^{3}\right), 1.76\left(\mathrm{ddd}, \mathrm{H}^{6}\right), 2.14\left(\mathrm{dddd}, \mathrm{H}^{6}\right), 2.24\left(\mathrm{dddd}, \mathrm{H}^{3}\right), 2.29\left(\mathrm{~m}, \mathrm{H}^{5}\right)$, $2.44\left(\mathrm{~m}, 2 \mathrm{H}, \mathrm{CH}_{2} \mathrm{~N}\right), 2.64\left(\mathrm{~m}, 2 \mathrm{H}, \mathrm{CH}_{2} \mathrm{~N}\right), 3.17\left(\mathrm{~m}, \mathrm{H}^{1}\right), 3.22\left(\mathrm{~m}, \mathrm{H}^{2}\right), 3.35\left(\mathrm{~s}, 6 \mathrm{H}, \mathrm{OCH}_{3}\right), 3.53$ $\left(\mathrm{dd}, 4 \mathrm{H}, \mathrm{CH}_{2} \mathrm{OMe}\right), 3.63\left(\mathrm{~m}, 12 \mathrm{H}, \mathrm{OCH}_{2}\right), 3.70\left(\mathrm{t}, 4 \mathrm{H}, \mathrm{OCH}_{2}\right), 3.79\left(\mathrm{dt}, \mathrm{H}^{4}\right), 4.26(\mathrm{~m}, 4 \mathrm{H}$, $\left.\mathrm{COOCH}_{2}\right), 4.57(\mathrm{~s}, \mathrm{OH}) .{ }^{13} \mathrm{C} \mathrm{NMR}\left(75 \mathrm{MHz}, \mathrm{CD}_{3} \mathrm{OD}\right): \delta 174.69,174.37(\mathrm{C}=\mathrm{O}), 72.97,71.55$, 
71.37, 71.36, 70.02, $70.00\left(\mathrm{OCH}_{2} \mathrm{CH}_{2} \mathrm{O}\right), 67.82(\mathrm{C} 5), 65.90(\mathrm{C} 4), 65.15,65.09\left(\mathrm{COOCH}_{2}\right), 59.10$ $\left(\mathrm{OCH}_{3}\right), 51.31\left(\mathrm{CH}_{2} \mathrm{~N}\right), 41.74(\mathrm{C} 1), 41.57(\mathrm{C} 2), 33.24(\mathrm{C} 3), 25.83,24.32\left(\mathrm{CH}_{2}\right.$ piperidyl $), 23.58$ (C6). MS/MS m/z (rel. intensity): 59.3 (14), 103.0 (16), 112.3 (22), 123.0 (11), 125.4 (14), 162.3 (12), 167.1 (22), 190.1 (60), 208.3 (23), 236.4 (21), 254.0 (13), 354.2 (51), 372.0 (11), 382.0 (12), 400.2 (64), $546.2(100), 564.1\left([\mathrm{M}+\mathrm{H}]^{+}, 65\right) . \quad \mathrm{HRMS}: \mathrm{C}_{27} \mathrm{H}_{49} \mathrm{NO}_{11}$ requires $[\mathrm{M}+\mathrm{H}]^{+}$ 564.3384, found 564.3367.

trans-19-Hydroxy-20-piperidyl-2,16-dioxo-3,6,9,12,15-pentaoxa-trans-bicyclo[15.4.0] heneicosane (11). Yield: 56\%. ${ }^{1} \mathrm{H}$ NMR (400 MHz, $\left.\mathrm{CD}_{3} \mathrm{OD}\right): \delta 1.48\left(\mathrm{~m}, 2 \mathrm{H}, \mathrm{CH}_{2}\right.$ piperidyl), $1.60(\mathrm{~m}$, 4H, $\mathrm{CH}_{2}$ piperidyl), $1.75\left(\mathrm{ddd}, \mathrm{H}^{3}\right), 1.83\left(\mathrm{ddd}, \mathrm{H}^{6}\right), 2.03\left(\mathrm{dddd}, \mathrm{H}^{6}\right), 2.08$ (dddd, $\left.\mathrm{H}^{3}\right), 2.29$ (dt, $\left.\mathrm{H}^{5}\right), 2.47\left(\mathrm{~m}, 2 \mathrm{H}, \mathrm{CH}_{2} \mathrm{~N}\right), 2.59\left(\mathrm{~m}, 2 \mathrm{H}, \mathrm{CH}_{2} \mathrm{~N}\right), 3.09\left(\mathrm{dt}, \mathrm{H}^{1}\right), 3.20\left(\mathrm{dt}, \mathrm{H}^{2}\right), 3.57\left(\mathrm{t}, 2 \mathrm{H}, \mathrm{OCH}_{2}\right)$, $3.65\left(\mathrm{~m}, 6 \mathrm{H}, \mathrm{OCH}_{2}\right), 3.71\left(\mathrm{t}, 4 \mathrm{H}, \mathrm{OCH}_{2}\right), 4.02\left(\mathrm{dt}, \mathrm{H}^{4}\right), 4.11\left(\mathrm{~m}, 2 \mathrm{H}, \mathrm{COOCH}_{2}\right), 4.33(\mathrm{~m}, 2 \mathrm{H}$, $\left.\mathrm{COOCH}_{2}\right), 4.81(\mathrm{~s}, \mathrm{OH}) .{ }^{13} \mathrm{C} \mathrm{NMR}\left(75 \mathrm{MHz}, \mathrm{CD}_{3} \mathrm{OD}\right): \delta 175.68,175.53(\mathrm{C}=\mathrm{O}), 71.74,71.68$, $69.80\left(\mathrm{OCH}_{2} \mathrm{CH}_{2} \mathrm{O}\right), 66.38(\mathrm{C} 5), 65.90(\mathrm{C} 4), 65.28,65.20\left(\mathrm{COOCH}_{2}\right), 51.88\left(\mathrm{CH}_{2} \mathrm{~N}\right), 41.52$ (C1), 41.34 (C2), 33.42 (C3), 25.56, 25.02 ( $\mathrm{CH}_{2}$ piperidyl), 24.40 (C6). MS/MS m/z (rel. intensity): 123.6 (12), 149.5 (14), 167.5 (48), 190.4 (34), 195.5 (23), 213.3 (18), 254.4 (13), 384.6 (14), $412.7(56), 430.3\left([\mathrm{M}+\mathrm{H}]^{+}, 100\right)$. HRMS: $\mathrm{C}_{21} \mathrm{H}_{35} \mathrm{NO}_{8}$ requires $[\mathrm{M}+\mathrm{H}]^{+} 430.2441$, found 430.2483 .

\section{Acknowledgements}

This research was supported by INTAS (Grant 94-1914), the Russian Foundation for Basic Research (Grant 94-03-09296), and the Department of Chemistry, University of the Pacific.

Eberhardt Research Fellowship from University of the Pacific is gratefully acknowledged by V.V.S.

Authors thank Dr. Andreas Franz, and Dr. Xiaoyi Hu (UOP) for their help in acquisition of MS data.

\section{References}

1. Molecular switches; Feringa, B. L., Ed.; Wiley-VCH: Weinheim, Chichester, 2001.

2. Schneider, H.-J.; Yatsimirsky, A. Principles and Methods in Supramolecular Chemistry; Wiley: Chichester, New York, 2000.

3. Takeuchi, M.; Ikeda, M.; Sugasaki, A.; Shinkai, S. Acc. Chem. Res. 2001, 34, 865.

4. Samoshin, V. V.; Subbotin, O. A.; Zelenkina, O. A.; Zefirov, N. S. Zh. Org. Khim. 1986, 22, 2231 (Russ. J. Org. Chem. 1986, 22, 2004).

5. Samoshin, V. V.; Zelenkina, O. A.; Subbotin, O. A.; Zefirov, N. S. Zh. Org. Khim. 1987, 23, 1319 (Russ. J. Org. Chem. 1987, 23, 1192).

6. Samoshin, V. V.; Zelenkina, O. A.; Yartseva, I. V.; Zefirov, N. S. Zh. Org. Khim. 1987, 23, 2244 (Russ. J. Org. Chem. 1987, 23, 1984). 
7. Samoshin, V. V.; Zelenkina, O. A.; Subbotin, O. A.; Sergeev, N. M.; Zefirov, N. S. Zh. Org. Khim. 1988, 24, 465 (Russ. J. Org. Chem. 1988, 24, 413).

8. Samoshin, V. V.; Yartseva, I. V.; Zelenkina, O. A.; Zefirov, N. S. Zh. Org. Khim. 1988, 24, 2455 (Russ. J. Org. Chem. 1988, 24, 2215).

9. Samoshin, V. V.; Zelenkina, O. A.; Yartseva, I. V.; Subbotin, O. A.; Zefirov, N. S. Zh. Org. Khim. 1988, 24, 2458 (Russ. J. Org. Chem. 1988, 24, 2217).

10. Samoshin, V. V.; Zapol'skiy, M. E.; Lutsenko, A. I.; Zelenkina, O. A.; Zefirov, N. S. Zh. Org. Khim. 1989, 25, 651 (Russ. J. Org. Chem. 1989, 25, 586).

11. Samoshin, V. V.; Zelenkina, O. A.; Zapol'skiy, M. E.; Vereshchagina, Y. A.; Zefirov, N. S. In Abstracts of $15^{\text {th }}$ International Symposium on Macrocyclic Chemistry; Odessa: USSR, 1990; p 182.

12. Samoshin, V. V.; Zefirov, N. S. In Abstracts of 16th International Symposium on Macrocyclic Chemistry; Sheffield: UK, 1991; p ST30.

13. Tsingarelli, R. D.; Shpigun, L. K.; Samoshin, V. V.; Zelyonkina, O. A.; Zapolsky, M. E.; Zefirov, N. S.; Zolotov, Y. A. Analyst 1992, 117, 853.

14. Potekhin, K. A.; Struchkov, Y. T.; Konoplyanko, N. V.; Samoshin, V. V.; Zefirov, N. S. Dokl. Akad. Nauk USSR 1992, 326, 1007 (Proc. Acad. Sci. USSR 1992, 326, 240).

15. Samoshin, V. V.; Konoplyanko, N. V.; Lutsenko, A. I.; Zefirov, N. S. Zh. Org. Khim. 1992, 28, 867 (Russ. J. Org. Chem. 1992, 28, 668).

16. Samoshin, V. V.; Vereshchagina, Y. A.; Konoplyanko, N. V.; Lutsenko, A. I.; Zefirov, N. S. Zh. Org. Khim. 1993, 29, 213 (Russ. J. Org. Chem. 1993, 29, 183).

17. Samoshin, V. V.; Vereshchagina, Y. A.; Lutsenko, A. I.; Zefirov, N. S. Zh. Org. Khim. 1993, 29, 1095 (Russ. J. Org. Chem. 1993, 29, 910).

18. Troyansky, E. I.; Ismagilov, R.F.; Samoshin, V.V.; Strelenko, Y.A.; Demchuk, D.V.; Nikishin, G.I.; Lindeman, S.V.; Khrustalev, V.N.; Struchkov, Y.T. Tetrahedron 1995, 51, 11431.

19. Samoshin, V. V.; Chertkov, V. A.; Vatlina, L. P.; Dobretsova, E. K.; Simonov, N.A.; Kastorsky, L. P.; Gremyachinsky, D. E.; Schneider, H.-J. Tetrahedron Lett. 1996, 37, 3981.

20. Samoshin, V. V.; Bychkova, O. V.; Chertkov, V.A.; Shestakova, A.K.; Vatlina, L.P.; Simonov, N. A.; Kastorsky, L. P. Zh. Org. Khim. 1996, 32, 1104 (Russ. J. Org. Chem. 1996, 32, 1066).

21. Samoshin, V. V.; Troyansky, E. I. Phosph., Sulf., Silicon 1997, 120/121, 181.

22. Samoshin, V. V.; Troyansky, E. I. In Abstracts of 213th National Meeting of the American Chemical Society San Francisco, USA, 1997, p ORGN 354.

23. Samoshin, V. V.; Chertkov, V. A.; Gremyachinskiy, D. E.; Dobretsova, E. K.; Shestakova, A. K.; Vatlina, L. P. Tetrahedron Lett. 2004, 45, 7823.

24. Raban, M.; Hortelano, E.; Quin, J.; King, N.; Koch, J. J. Chem. Soc., Chem. Commun. 1985, 1557.

25. Raban, M.; Quin, J.; Belguise, A. Tetrahedron Lett. 1991, 32, 35.

26. Raban, M.; Burch, D.L.; Hortelano, E.R.; Durocher, D. J. Org. Chem. 1994, 59, 1283. 
27. Raban, M.; Quin, J.; Belguise, A.; Durocher, D.; Kost, D. Chirality 1998, 10, 78.

28. Costero, A. M.; Rodriguez, S. Tetrahedron Lett. 1992, 33, 623.

29. Costero, A. M.; Rodriguez, S. Tetrahedron 1992, 48, 6265.

30. Costero, A. M.; Villarroya, J. P.; Gil, S.; Aurell, M. J.; de Arellano, M. C. R. Tetrahedron 2002, 58, 6729.

31. Costero, A. M.; Villarroya, J. P.; Gil, S.; Gavina, P.; Ramirez De Arellano, M. C. Supramol. Chem. 2003, 15, 403.

32. Costero, A. M.; Villarroya, J. P.; Gil, S.; Martinez-Manez, R.; Gavina, P. C. R. Chimie 2004, 7,15 .

33. Berninger, J.; Krauss, R.; Weining, H.-G.; Koert, U.; Ziemer, B.; Harms, K. Eur. J. Org. Chem. 1999, 875.

34. Krauss, R.; Weining, H.-G.; Seydack, M.; Bendig, J.; Koert, U. Angew. Chem., Int. Ed. 2000, 39, 1835.

35. Koert, U.; Krauss, R.; Weining, H.-G.; Heumann, C.; Ziemer, B.; Mügge, C.; Seydack, M.; Bendig, J. Eur. J. Org. Chem. 2001, 575.

36. Weining, H.-G.; Krauss, R.; Seydack, M.; Bendig, J.; Koert, U. Chem. Eur. J. 2001, 7, 2075.

37. Karle, M.; Bockelmann, D.; Schumann, D.; Griesinger, C.; Koert, U. Angew. Chem., Int. Ed. 2003, 42, 4546.

38. Krauss, R.; Koert, U. Synlett 2003, 598.

39. Whelton, B.D.; Lowry, B.R.; Carr, J.B.; Huitric, A.C. J. Pharm. Sci. 1973, 62, 728.

40. Tichy, M. Coll. Czech. Chem. Commun. 1973, 38, 3631.

41. Zefirov, N. S.; Samoshin, V. V.; Subbotin, O. A.; Baranenkov, V. I.; Wolfe, S. Tetrahedron 1978, 34, 2953.

42. Longevialle, P.; Girard, J.-P.; Rossi, J.-C.; Tichy, M. Org. Mass Spec. 1980, 15, 268.

43. Eliel, E. L. Chem. Ind. 1959, 568.

44. Girard, J.-P.; Rossi, J.-C.; Escale, R.; Vasickova, S.; Tichy, M. Coll. Czech. Chem. Commun. 1977, 42, 90.

45. Pavia, A.; Winternitz, F.; Wylde, R. Bull. Soc. Chim. France 1966, 2506.

46. Schneider, H.-J.; Buchheit, U.; Gschwendtner, W.; Lonsdorfer, M. In Molecular Structure and Biological Activity; Griffin, J. F., Duax, W. L., Eds; Elsevier: New York, 1982; p 165.

47. Kooijman, H.; Kelder, J.; Kanters, J. A.; Duisenberg, A. J. M.; Kroon, J. J.Chem.Soc., Perkin Trans. 2 1996, 2133.

48. Eliel, E. L.; Wilen, S. H.; Mander, L. N. Stereochemistry of organic compounds; Wiley: New York, 1994.

49. Tichy, M.; Vasickova, S.; Arakelian, S. V.; Sicher, J. Coll. Czech. Chem. Commun. 1970, 35,1522 .

50. (a) Serena Software, Bloomington, IN. (b) Gajewski, J. J.; Gilbert, K. E.; McKelvey, J. In: Advances in Molecular Modeling; Liotta, D., Ed.; JAI Press: Greenwich, CT, 1990; Vol. 2, p 65 . 